\title{
Characteristics of Microbiological and Physicochemical of Complementary Foods Based on Maize (Zea mays) Fortification With Bambara Groundnut (Vigna subterranea)
}

\author{
T. I. Mbata ${ }^{1} \&$ S. Adeyemo ${ }^{2}$ \\ ${ }^{1}$ Department of Biology/Microbiology, Federal Polytechnic Nekede, Owerri, Nigeria \\ ${ }^{2}$ Department of Maths/Satistics, Federal Polytechnic Nekede Owerri, Nigeria \\ Correspondence: T. I. Mbata, Department of Biology/Microbiology, Federal Polytechnic Nekede, 1036, Owerri, \\ Nigeria. Tel: 234-80-326-18922. E-mail: proftheodore@gmail.com; theodore.mbata@fpno.edu.ng
}

$\begin{array}{ll}\text { Received: January 15, } 2020 & \text { Accepted: March 28, } 2020 \quad \text { Online Published: April 15, } 2020 \\ \text { doi:10.5539/jas.v12n5p9 } & \text { URL: https://doi.org/10.5539/jas.v12n5p9 }\end{array}$

\begin{abstract}
Protein-energy malnutrition is regarded as one of the public health problems in developing countries as a result of poor feeding practices due to poverty. The study was aimed at formulating complementary foods using on maize and Bambara groundnut with a view of reducing malnutrition in low income families. The blends $70 \%$ maize, 30\% Bambara groundnut were subjected into proximate, sensory and biochemical analyses using standard procedures. Nutrend (a commercial formula) was used as control. The effect of some processing techniques such as germination, roasting, fermentation, boiling, and soaking were determined. The results obtained showed protein content were $15.0 \%$ for roasted Bambara groundnut maize germinated flour (RBMGF), $13.80 \%$ for boiled Bambara groundnut maize germinated flour (BBMGF), 15.18\% for soaked Bambara groundnut maize germinated flour (SBMGF), values for maize flour and nutrend had $10.4 \%$ and $23.21 \%$ respectively. Energy value of RBMGF, BBMGF, SBMGF, maize flour and nutrend were 494.9, 348.97, 356.49, 351 and $467.2 \mathrm{kcal}$, respectively. The antinutrient composition of roasted Bambara groundnut maize germinated flour (RBMGF) and boiled Bambara groundnut maize germinated flour (BBMGF) were lower than of soaked Bambara groundnut maize germinated flour (SBMGF). The overall acceptability of SBMGF was rated higher than RBMGF, BBMGF and Maize flour, but lower than Nutrend. Microflora gradually changed from gram negative enteric bacteria such as Escherichia coli, Klebsiella spp. and Enterobacter aerogenes, mold such a Penicillium citrinum, lactic acid bacteria such as Lactobacillus plantarum, Lactobacillus acidophilus, Lactobacillus fermentum, and Lactobacillus delbrueckii subsp. bulgaricus and yeast, such as Saccharomyces cerevisae to be dominated by Gram positive lactic acid bacteria (LAB) and yeasts. Yeasts and LAB growth counts in the complementary food varied between 4.44 and $7.36 \mathrm{log} \mathrm{cfu} / \mathrm{ml}$. LAB number increased from 5.40 to $7.36 \mathrm{log} \mathrm{cfu} / \mathrm{ml}$ during fermentation. Yeasts increased from 4.44 to $5.60 \mathrm{log} \mathrm{cfu} / \mathrm{ml}$. The use of Bambara groundnut fortification to traditional foods could promote the nutritional quality of African maize-based traditional food.
\end{abstract}

Keywords: Bambara groundnut, complementary food, fortification, maize, microbiological, physicochemical

\section{Introduction}

Malnutrition is widespread in both rural and urban communities in Nigeria. This is due to strict economic measure, inadequate production and supply of foods, especially protein and micronutrients rich foods. There are little advances in the processing and preservation techniques and neglect of our indigenous crops (Agbaje et al., 2017). Maize processing in West Africa is based on traditional indigenous technology, which utilizes local raw materials, and in most cases, local equipment. These technologies are simple, with most of them having been developed through experience in the production of products of desirable quality (Sefa-Dedeh \& Mensah, 1991). Maize is processed into a wide range of foods and beverages ranging from weaning and children's breakfast porridge to adult main meals and snack foods (Plahar \& Leung, 1983).

Traditional foods are formulated based on local staple usually cereal grains, such as maize, sorghum, millet and rice, roots and tubers such as, yam, cassava etc. (Akpapunam \& Sefa-Dedeh, 1995). The reasons because artificial complementary foods are expensive, especially among the low income group cannot afford them. Such families often depend on inadequate processed traditional foods consisting mainly of supplemented cereal 
porridge (Agbaje et al., 2017). To be suitable for the feeding of young children, the cereals are prepared in liquid form by diluting with a large quantity of water, thereby resulting in a large volume with low energy and nutrient density (Onilude et al., 1999). Many brands of low-cost proprietary weaning foods have been developed from locally available high calorie cereals and legumes in tropical Africa (Mahgoub, 1999).

This has been suggested by the integrated child development scheme (ICDS) and FAO to combat malnutrition among mothers and children of low socio-economic groups. Evidence indicates that it is quite possible to improve the nutrient quality and acceptability of these cereals and legumes and exploit their potentials as human foods by adopting newer scientific processing methods (Adelekan \& Oyewole, 2010)

Germination or fermentation by lactic acids has been reported as ways of improving cereal-protein quality (Buta \& Emire, 2015). Despite the reported improvement in the nutrient status of germinated and fermented cereal based diets in sub-Saharan Africa, the nutrient needs of infants and sick adults are still not being met.

Earlier studies have documented the need for fortification of traditional fermented maize porridge with legume (Nti \& Plahar, 1995; Okwunodulu et al., 2020). Despite the various reports, information on the effect of different processing and physicochemical methods on Bambara-groundnut fortification on the nutritive value of some maize based traditional foods is scarce. Based on these facts, the study was undertaken to characterize microbiological and physicochemical of complementary foods based on maize (Zea mays) fortification with Bambara groundnut (Vigna subterranea).

\section{Materials and Methods}

\subsection{Source of Sample}

Weighed $3.0 \mathrm{~kg}$ of yellow maize (Zea mays) (DMR-LSR Y) and $6.0 \mathrm{~kg}$ of cream coat Bambara groundnut (Vigna subterreanea) clean seeds were obtained from local markets in Owerri, Southeast of Nigeria. The plants were authenticated by a botanist, Dr Christopher Duru, Federal University of Technology, Owerri, Nigeria.

\subsection{Processing Methods}

The procedures used were simple household technologies that are commonly used for daily food preparation in Nigeria. They have been suggested to improve the nutritional characteristics of foods (Keregero \& Kurwijilla, 1987).

\subsubsection{Bambara Groundnut}

The Bambara groundnut seeds were sorted, cleaned divided into four groups of $1.5 \mathrm{~kg}$ each. The first group was left raw, while the second group was boiled in water at ratio of 1:10 (w/v) in a wide aluminum pot. Boiling was for $60 \mathrm{~min}$ at $100{ }^{\circ} \mathrm{C}$. Thereafter, the boiled seeds were de-hulled by hand rubbing and drained off the cooking water (Ayinde \& Olusegun, 2003). The third group were soaked in distilled water for $6 \mathrm{~h}$ at room temperature $\left(28 \pm 2{ }^{\circ} \mathrm{C}\right)$ in a seeds to water ratio of $1: 10(\mathrm{w} / \mathrm{v})$. The fourth group of seeds was roasted for $30 \mathrm{~min}$ at $70{ }^{\circ} \mathrm{C}$. The soaked and roasted seeds were dehulled by hand rubbing to reduce the beany flavor. The batch of raw seeds was stored as such without any treatment. After each treatment, the processed seed samples were rinsed with distilled water separately and then dried at $70{ }^{\circ} \mathrm{C}$ for $3 \mathrm{~h}$ in a hot air oven (Alozie et al., 2009). All the processed as well as raw seed samples were powdered and milled using attrition mill supplied by Asiko All Adis, Nigeria, Ltd and sieved through $500 \mu \mathrm{m}$ mesh screen to obtain fine Bambara groundnut flour. The different Bambara flours were each stored in sealed plastic containers at $28 \pm 2{ }^{\circ} \mathrm{C}$ prior to use.

\subsubsection{Yellow Maize Flour}

Yellow maize grains were washed in a $5 \%(\mathrm{w} / \mathrm{v})$, sodium chloride $(\mathrm{NaCl})$ solution to suppress growth of moulds. They were then steeped in tap water at room temperature $\left(28 \pm 2{ }^{\circ} \mathrm{C}\right)$ in a ratio of $1: 3(\mathrm{w} / \mathrm{v})$ grain:water in a plastic bucket. The water were changed every $4 \mathrm{~h}$ to prevent fermentation for a total steeping time of $12 \mathrm{~h}$. The seeds were then placed in a plastic basket for drainage of water after which they were spread in a single layer on a moistened jute bag and allowed to sprout in a wooden malting box for $48 \mathrm{~h}$ using the modified method of Ayernor and Ocloo (2007). Ungerminated grains were discarded while the germinated grains with the sprouts were oven dried at $70{ }^{\circ} \mathrm{C}$ for $30 \mathrm{~min}$. The dried grains were split in a disc attrition mill supplied by Asiko All Adis, Nigeria Ltd. The testa and rootlets detached from the cotyledon during splitting were separated by winnowing. The cotyledons were then ground into flour in the disc attrition mill supplied by Asiko All Adis, Nigeria Ltd. followed by sieving through $500 \mu \mathrm{m}$ wire mesh. The flours were packaged in plastic containers with airtight lids and stored at $28 \pm 2{ }^{\circ} \mathrm{C}$ prior to use. 


\subsection{Formulation of Bambara-Maize Weaning Food}

Bambara groundnut flour from different processing methods and maize germinated flour were blended in the ratio 30:70 (w/w) as described by Ijarotimi et al. (2009). The flours were used to formulate the Bambara-maize weaning food in the following ratio:

$\mathrm{A}=70 \%$ sprouted maize flour (SMF): $30 \%$ roasted Bambara groundnut flour (RBF);

$\mathrm{B}=70 \%$ sprouted maize flour (SMF): $30 \%$ boiled Bambara groundnut flour (BBF);

$\mathrm{C}=70 \%$ sprouted maize flour (SMF): 30\% soaked Bambara groundnut flour (SBF) (Figure 1).

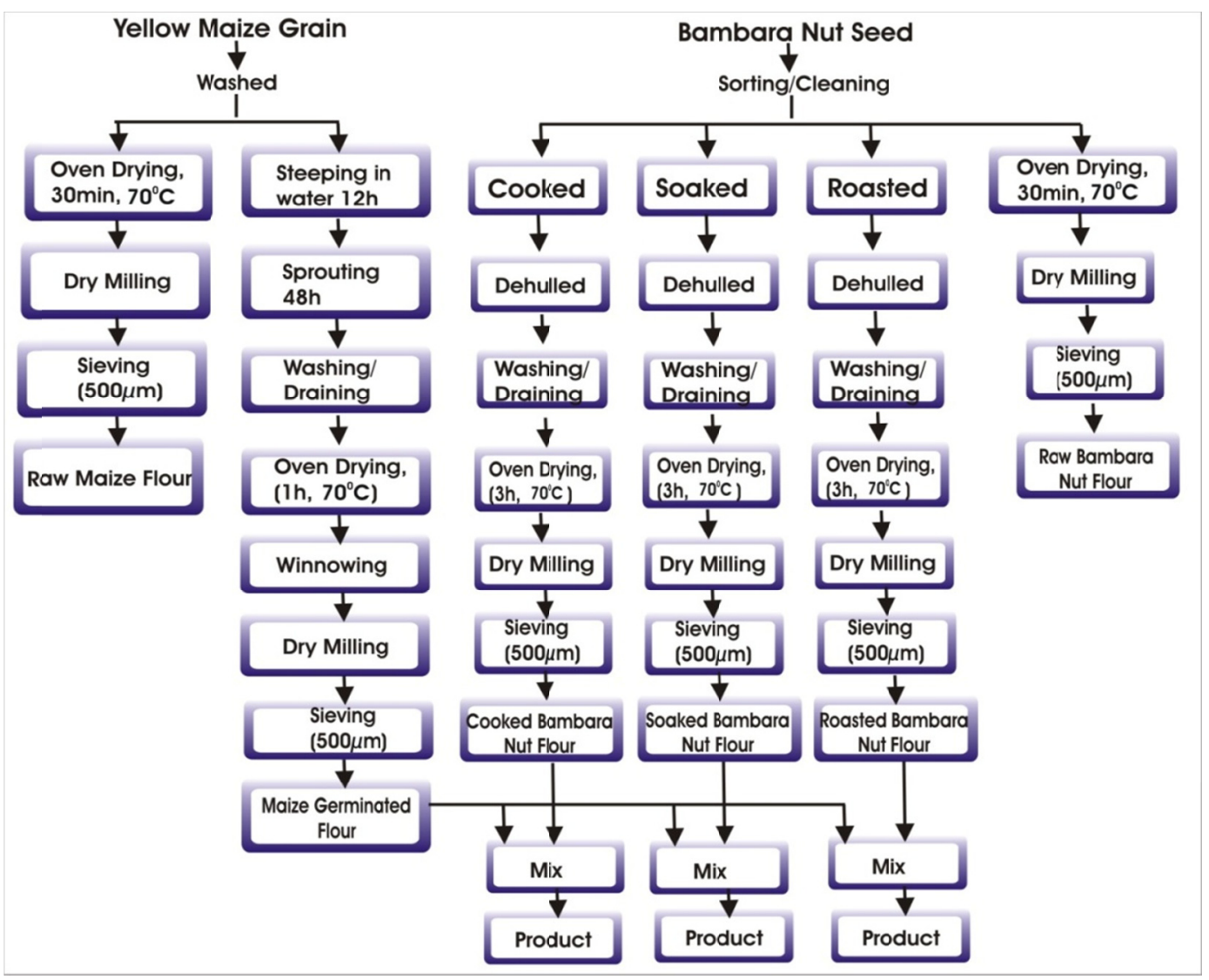

Figure 1. Flow chart of processing of Bambara groundnut-maize flour using different processing method

\subsection{Microbial Analyses}

At $12 \mathrm{~h}$ intervals $(0,12,24,36,48$ and $72 \mathrm{~h}), 10 \mathrm{~g}$ of sample were homogenized in $90 \mathrm{ml}$ of sterile $0.1 \%$ peptone water for $30 \mathrm{~s}$. The homogenates were serially diluted in sterile peptone water diluent. From the 10-fold dilutions of the homogenates, $0.1 \mathrm{ml}$ of $10^{-4}, 10^{-5}$ and $10^{-6}$ dilutions of the homogenates were plated in replicate on different media (in duplicates), using spread plate method (Kiiyukia, 2003). The plates were incubated on Mann Rogosa-Sharpe (MRS) Agar (Oxoid, UK) at $37{ }^{\circ} \mathrm{C}$ for $48 \mathrm{~h}$ (for the cultivation of lactobacilli), sabouraud dextrose Agar (SDA) (LAB M, idgplc, UK) at $28 \pm 2{ }^{\circ} \mathrm{C}$ for $72 \mathrm{~h}$ (for isolation of dermatophytes, other fungi and yeasts), MacConkey Agar (a selective and differential medium to isolate and differentiate enterics based on their ability to ferment lactose) and Nutrient Agar (Oxoid), UK) at $37{ }^{\circ} \mathrm{C}$ for $48 \mathrm{~h}$ (general purpose medium supporting growth of a wide range of non-fastidious organisms).

\subsection{Isolation and Characterization of Bacteria}

At end of the incubation period, colonies were counted using the illuminated colony counter (Gallenkamp, England). The counts for each plate were expressed as colony forming unit of the suspension (cfu/ml). Discrete colonies were sub cultured into fresh agar plates aseptically to obtain pure cultures of the isolates. Pure isolates of resulting growth were stored at $4{ }^{\circ} \mathrm{C}$ before being tested for Gram reaction (Claus, 1992). Bacteria isolates 
were grouped according to their colony appearance and cell morphology and also identified by biochemical tests by comparing their characteristics with those of known taxa, using Bergey's Manual of Determinative Bacteriology as described by Sneath et al. (1986).

\subsection{Isolation and Characterization of Yeasts and Moulds}

At $12 \mathrm{~h}$ intervals, the incubated plates $\left(28 \pm 2{ }^{\circ} \mathrm{C}\right.$ for $\left.72 \mathrm{~h}\right)$ were observed for fungal growth and the colonies will be randomly selected from the SDA plates used for fungal counts. The isolates were purified by repeated spreading using the same medium and incubation conditions of the original isolation, and then will be stored on SDA slants at $4^{\circ} \mathrm{C}$ before characterization.

Microscopic examination of the mould were studied by performing a wet mount using lacto phenol cotton blue mounting fluid; the preparation was examined first under low power and then high power objective lenses. The fungi were identified as described by Frey et al. (1979). Representative yeast isolates were identified to the level of species according to the procedure of Kreger-Van Rij (1984).

\subsection{Extraction of DNA and Purity Test}

Measured $1.5 \mathrm{~mL}$ of an overnight broth culture was added into eppendorf tubes and centrifuged at 14,000 (rpm), as described by the method of Onyenwe et al. (2012).

\subsubsection{PCR Amplification and Agarose Gel Electrophoresis}

The purified DNA template in PCR eppendorf tubes $(2.0 \mu \mathrm{L}$ DNA) was mixed with the Master Mix ready to load (HOT FIREPol ${ }^{\circledR}$ DNA polymerase with $\mathrm{MgCl}_{2}$, Germany). The $\mathrm{MgCl}_{2}$ were varied according to the manufacturers recommendation on the specific primer sequence of the Lactobacillus species used. The mixture of primers, DNA and the Master Mix were vortexed, to mix and then centrifuged before introducing it into the PCR machine (Eppendorf-Germany) as described by Onyenwe et al. (2012).

\subsection{Physico-Chemical Analysis During Fermentation}

\subsection{1 pH Determination During Fermentation}

The $\mathrm{pH}$ of the samples was determined according to the method of AOAC (2000). Weighed $10 \mathrm{~g}$ of sample was mixed in $100 \mathrm{~mL}$ distilled water. The mixture was allowed to stand for $15 \mathrm{~min}$, shaken at $5 \mathrm{~min}$ interval and filtered with Whatman No.14 filter paper. The $\mathrm{pH}$ of the filtrate was measured using a $\mathrm{pH}$ meter (Model HM-305, Tokyo, Japan).

\subsubsection{Titratable Acidity (T.A.)}

Measured $10 \mathrm{~mL}$ aliquots (triplicates) prepared from $8 \mathrm{~g}$ of sample diluted with $80 \mathrm{~mL}$ of distilled water (AOAC, 2000 ) were pipetted and titrated against $0.1 \mathrm{M} \mathrm{NaOH}$ to phenolphthalein end-point. The result was expressed as $g$ lactic acid/100 g sample.

\subsection{Proximate Composition of Complementary Foods}

Proximate parameters were determined for the formulated complementary food samples using standard procedures as described by AOAC (2000).

\subsection{Antinutritional Factors of Complementary Foods}

The antinutritional properties (trypsin inhibitor, tannin, phytate, and oxalate) of the samples were determined as described by AOAC (2000).

\subsection{Sensory Evaluation of Complementary Food}

Sensory characteristics of the blended Bambara-maize dough products were assessed by boiling $10 \%(\mathrm{w} / \mathrm{v})$ slurry of the dough for $15 \mathrm{~min}$ and their color, texture, flavor (aroma), taste and overall acceptability were assessed. The respondents were instructed to sip water before and after assessing each product. The respondent's recorded sensory characteristics of each sample using 8-point hedonic scale as described by Ihekoronye and Ngoddy (1991), where,

8 = like extremely: 4 = dislike slightly;

7 = like very much: 3 = dislike moderately;

6 = like moderately: 2 = dislike very much;

5 = like slightly: $1=$ dislike extremely.

Each treatment was evaluated three times by each panelist. 


\subsection{Statistical Analysis}

The data were analyzed using SPSS (Statistical Package for Social Sciences) version 20. The mean and standard error of means (SEM) of the triplicate analyses were calculated. The analysis of variance (ANOVA) was performed to determine the level of significant differences between the means of formulated food samples using Least Square Deviation (LSD) at $\mathrm{p}<0.05$.

\section{Results}

The results of the microbial counts and isolation from Bambara groundnut-maize germinated meals are shown in Table 1 and Figures 2-5. Yeast, molds, coliforms and lactic acid bacteria were also enumerated during the fermentation. The microflora gradually altered from Gram-negative enteric bacteria, molds, lactic acid bacteria and yeast to be dominated by Gram-positive lactic acid bacteria (LAB) and yeast. Coliforms and molds were present at the start of fermentation $(0$ and $12 \mathrm{~h})$ but were not detected after $24 \mathrm{~h}$ of fermentation. Yeasts and LAB numbers in the blends varied between 4.44 and $7.36 \log _{10} \mathrm{cfu} / \mathrm{mL}$. LAB number increased from 5.40 to 7.36 $\log _{10} \mathrm{cfu} / \mathrm{mL}$ during fermentation. Yeasts increased from 4.44 to $5.60 \log _{10} \mathrm{cfu} / \mathrm{mL}$. Table 2 shows the effect of Bambara groundnut treatment, and rate of fermentation of traditional maize dough. The addition of Bambara groundnut or heat treatment of the dough accelerated acid production. The steeping of maize grains generally encouraged higher lactic acid production by the prevailing microorganism. The Bambara-groundnut blend with the maize resulted in an increased in titratable acidity during the different periods of fermentation. The $\mathrm{pH}$ of the formulated food decreased (4.6-3.6) as fermentation progressed.

Results of the proximate nutrient composition of the compounded diets (diets1-5) are presented in Table 3. It was observed that there are significant differences $\mathrm{p}<0.05$ in values of the moisture content of all the diets. While commercial weaning food had moisture content $1.3 \%$. Values for crude protein were significantly higher $(\mathrm{p}<0.05)$ in all the compounded diets (RBMGF, 15.0\%, BBMGF, 13.80\%, SBMGF, 15.18\%) than maize flour but lower than commercial weaning food $(23.21 \%)$ and Bambara groundnut flour $(20.2 \%)$. Crude fat was observed to be significantly higher $(\mathrm{p}<0.05)$ in all the compounded local diets $(10.7-28.1 \%)$ than in the control $(3.72 \%)$ while the total carbohydrate value was significantly higher $(p<0.05)$ in the locally formulated diets than in the control (Table 3). Crude fibre was however found to be lower in the local formulated diets BBMGF (3.9\%), SBMGF (3.8\%) except RBMGF $(0.1 \%)$ than the control $(1.0 \%)$ and maize flour $(9.7 \%)$. Ash was significantly higher $(\mathrm{p}<0.05)$ in local diets $(2.8-4.2 \%)$ than the control $(2.1 \%)$. Energy values in all the local diets and the control were comparable $(\mathrm{p}>0.05)$.

The antinutrient composition of the formulated food samples are shown in Table 4 . The oxalate and phytate contents of RBMGF and BBMGF were significantly lower than those of soaked Bambara groundnut maize germinated flour (SBMGF), $(\mathrm{p}<0.05)$. The tannin and trypsin inhibitor contents of roasted Bambara groundnut maize germinated flour (RBMGF) and boiled Bambara groundnut maize germinated flour (BBMGF) mixes were insignificantly low when compared with those of soaked Bambara groundnut maize germinate flour mixes $(\mathrm{p}>$ $0.05)$.

The sensory attributes of formulated food samples and Nutrend samples are presented in Table 5. The sensory properties of Nutrend food samples in term of color, aroma, taste, mouth feel and overall acceptability were significantly higher than the formulated food samples $(p<0.05)$. The formulated diets scores were significantly low compared to the commercial weaning food) $(\mathrm{p}<0.05)$. The low rating of the formulated diet samples in term of aroma, taste, texture and color compared with commercial weaning food could be attributed to the familiarity of commercial weaning food to the panel of respondents. 


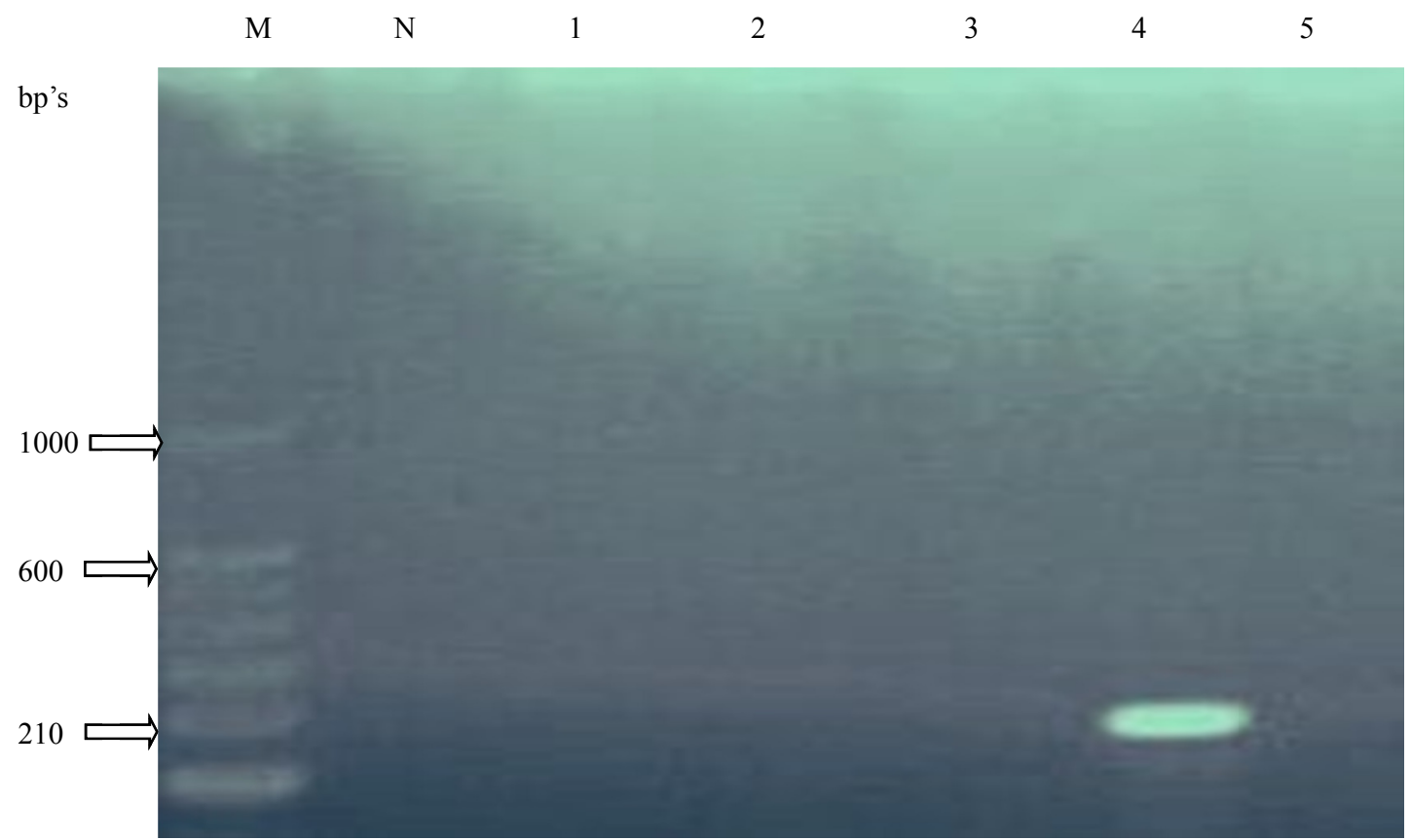

Figure 2. Agarose gel electrophoresis pattern showing single PCR amplification products of the Lactobacillus acidophilus (16s gene) on lane 4 with an amplicon size of $210 \mathrm{bps}$. Lane $\mathrm{N}$ shows the negative control, while lanes 1,2, 3 and 5 were negative for the specie of Lactobacillus acidophilus specific primer used for the identification of the isolates. Lane M shows the DNA molecular marker,

Random Amplified Polymorphic DNA (100-bp ladder)

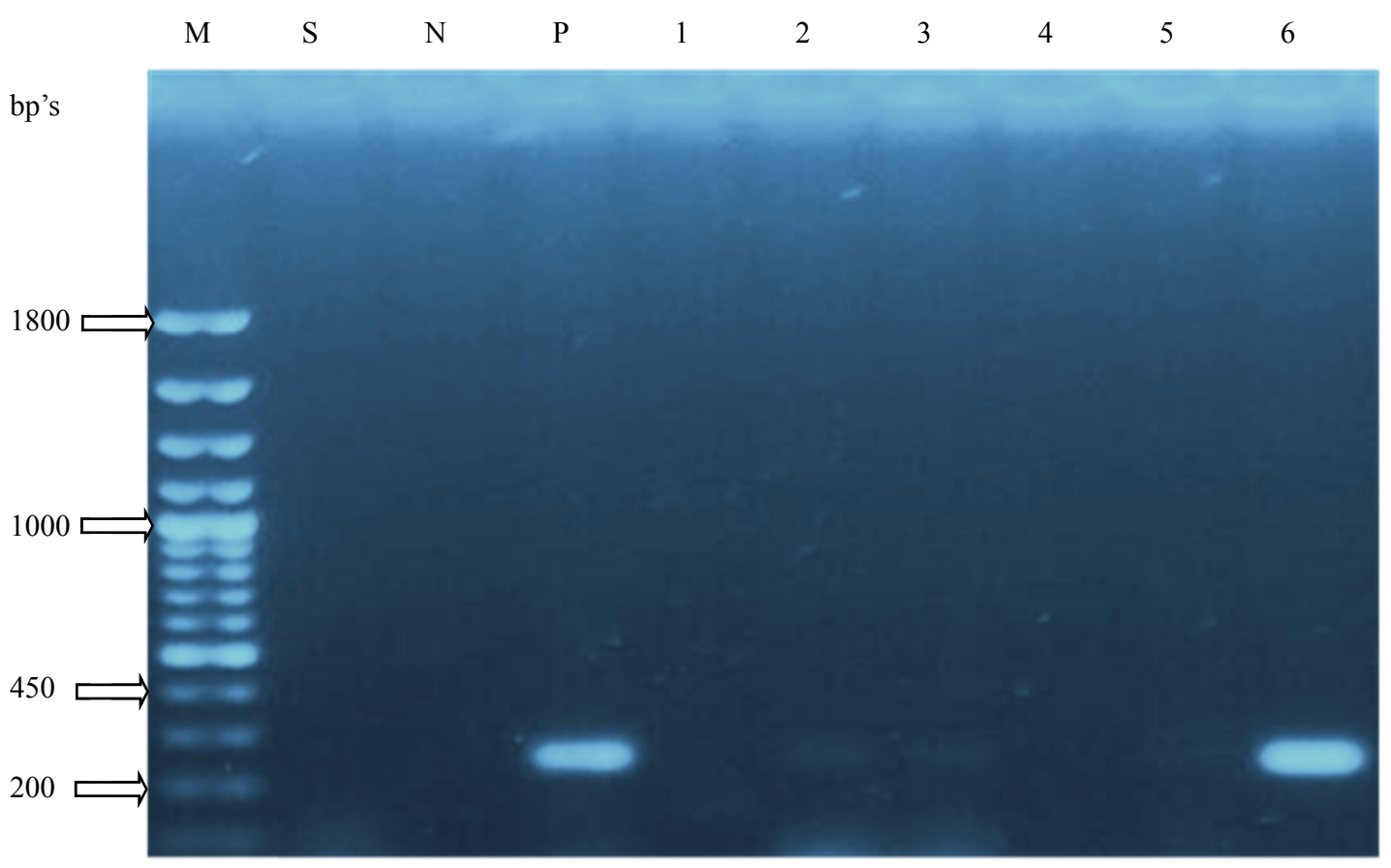

Figure 3. Agarose gel electrophoresis pattern showing single PCR amplification products of (16S-23s) spacer gene Lactobacillus delbrueckii subsp. bulgaricus. Lane P shows a positive L. delbrueckii subsp. bulgaricus (strain ATCC 11842). Lane 6 shows the Lactobacillus delbrueckii subsp. bulgaricus isolated from the cereal with the amplicon size of 450 bp's. Lane M shows the marker, Lane $\mathrm{S}$ is sterile water. Lane $\mathrm{N}$ shows a negative control of Lactobacillus spp. 


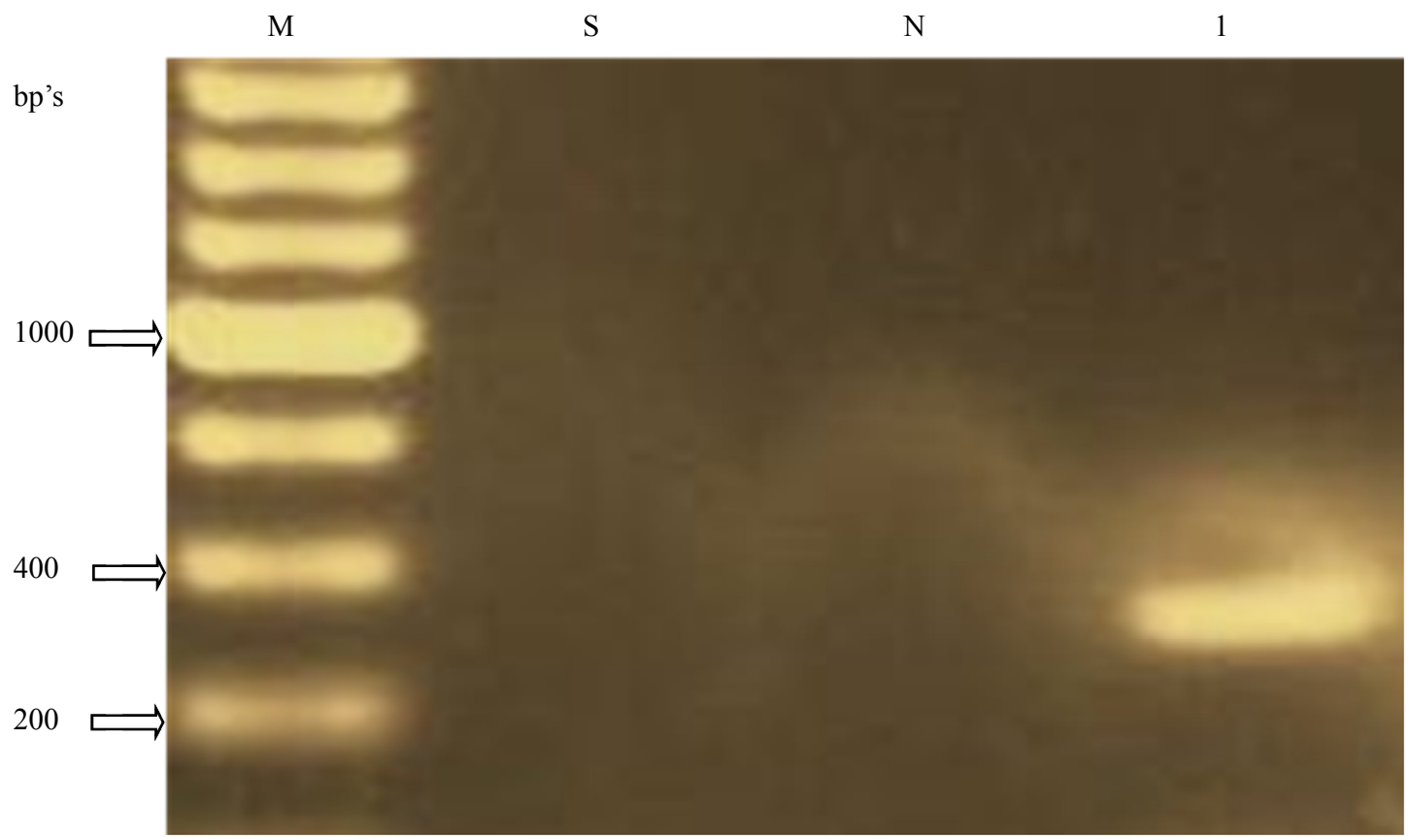

Figure 4. Agarose gel electrophoresis pattern showing single PCR amplification products of Lactobacillus plantarum (16S-23s) spacer gene. Lane $\mathrm{S}$ and $\mathrm{N}$ shows the sterile water and negative control sample respectively, while Lane 1 shows the positive Lactobacillus plantarum with the amplicon size of 248 bp's. Lane M shows the DNA molecular marker of 200 bp's

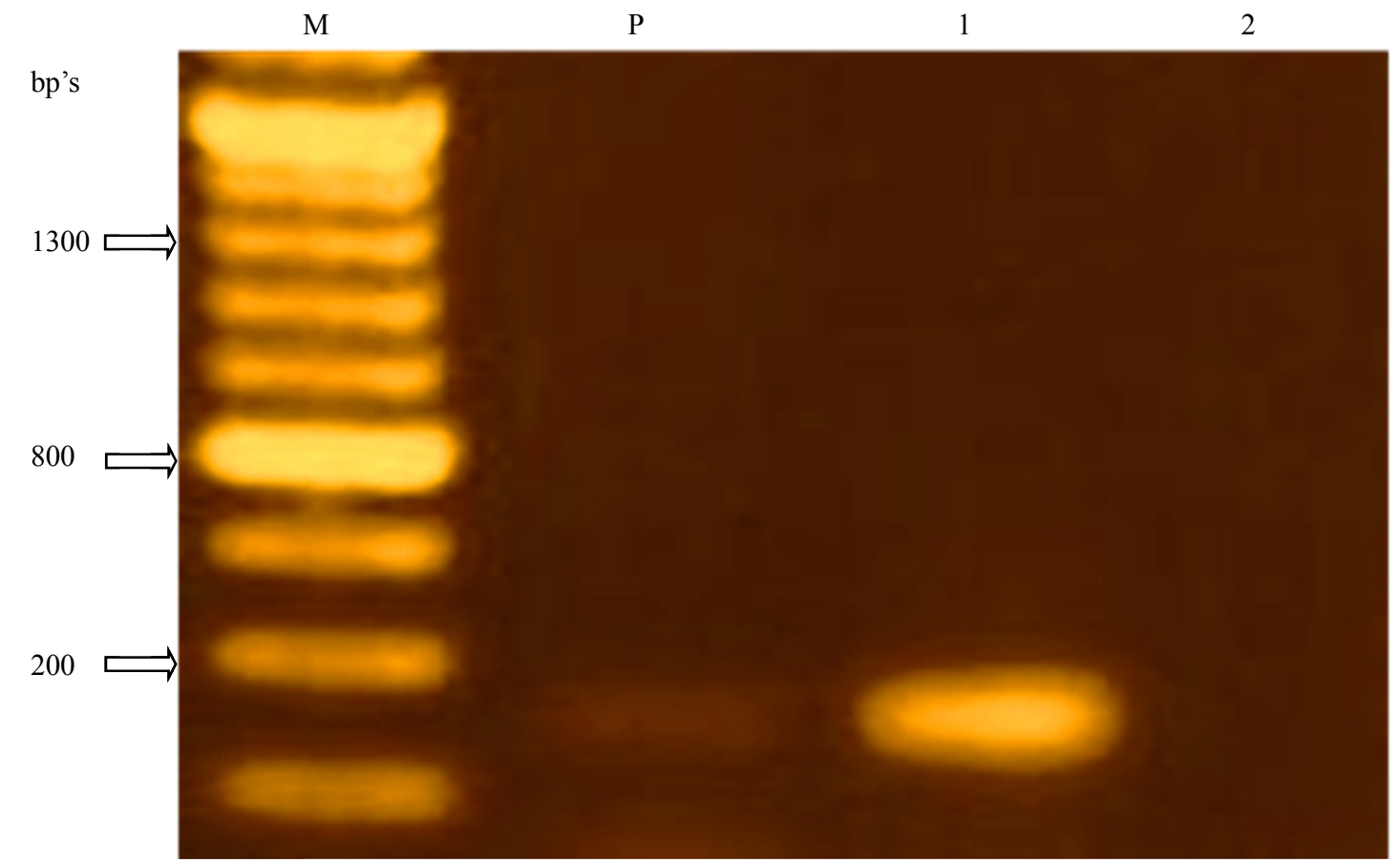

Figure 5. Agarose gel electrophoresis pattern showing single PCR amplification products of Lactobacillus fermentum (16S-23s) spacer gene. Lane 1 shows the positive Lactobacillus fermentum with the amplicon size of 192 bp's. Lane M shows the DNA molecular marker of 100 bp's.

Lane P shows a positive Lactobacillus fermentum 
Table 2. Effects of pH and titratable acidity on Bambara groundnut and fortification method of traditional maize dough

\begin{tabular}{|c|c|c|c|c|c|c|c|c|}
\hline \multirow{2}{*}{ Bambara-nut fortification (level and treatment) } & \multicolumn{4}{|c|}{$\mathrm{pH}$} & \multicolumn{4}{|c|}{ Titratable acidity } \\
\hline & 0 & 24 & 48 & 72 & 0 & 24 & 48 & 72 \\
\hline Control traditional dough $(0 \%)$ Bambara groundnut & $6.55^{\mathrm{a}}$ & $4.5^{\mathrm{ab}}$ & $4.0^{\mathrm{a}}$ & $3.6^{\mathrm{c}}$ & $1.3^{\mathrm{d}}$ & $5.3^{\mathrm{c}}$ & $6.2^{\mathrm{c}}$ & $6.5^{\mathrm{e}}$ \\
\hline Fortification level $30 \%$ Bambara groundnut & $4.60^{\mathrm{b}}$ & $3.90^{\mathrm{b}}$ & $3.75^{\mathrm{a}}$ & $3.62^{\mathrm{c}}$ & $5.0^{\mathrm{a}}$ & $8.0^{\mathrm{a}}$ & $8.4^{\mathrm{b}}$ & $10.6^{\mathrm{a}}$ \\
\hline
\end{tabular}

Note. Means of 3 independent determinations on dry weight basis.

Mean values in the same column with different superscripts differ significantly $(\mathrm{p}<0.05)$.

Table 3. Proximate composition of Bambara groundnut-maize composite blends

\begin{tabular}{|c|c|c|c|c|c|c|c|}
\hline Sample & Moisture & Crude Protein & Crude Fat & Crude fibre & Ash & Total CHO & Energy \\
\hline & \multicolumn{6}{|c|}{ 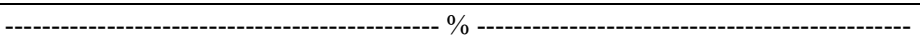 } & Kcal \\
\hline Roasted Bambara-maize malted flour & $3.3 \mathrm{~b}$ & $15.0 \mathrm{c}$ & $21.3 \mathrm{~d}$ & $0.1 \mathrm{a}$ & $2.8 \mathrm{~b}$ & $57.5 \mathrm{ab}$ & $494.9 \mathrm{~d}$ \\
\hline Boiled Bambara-maize malted flour & $11.24 \mathrm{c}$ & $13.80 \mathrm{e}$ & $5.27 \mathrm{~b}$ & $3.91 b$ & $4.20 \mathrm{ab}$ & $61.58 \mathrm{~d}$ & $348.97 \mathrm{e}$ \\
\hline Soaked Bambara-maize malted flour & $10.14 \mathrm{ab}$ & $15.18 \mathrm{c}$ & $5.77 \mathrm{~b}$ & $3.77 \mathrm{~b}$ & $4.18 \mathrm{ab}$ & $60.96 \mathrm{~d}$ & $356.49 \mathrm{e}$ \\
\hline Bambara flour & $7.50 \mathrm{a}$ & $18.20 \mathrm{~b}$ & $4.00 \mathrm{c}$ & $3.00 \mathrm{~b}$ & $3.70 \mathrm{c}$ & $63.60 \mathrm{ab}$ & $363.2 \mathrm{e}$ \\
\hline Maize flour & $9.7 \mathrm{~d}$ & $9.4 \mathrm{a}$ & $5.40 \mathrm{~b}$ & $7.7 \mathrm{c}$ & $1.60 \mathrm{a}$ & $66.20 \mathrm{~d}$ & $351 \mathrm{e}$ \\
\hline Nutrend & $1.3 \mathrm{e}$ & $23.21 \mathrm{~d}$ & $15.96 \mathrm{a}$ & $1.0 \mathrm{~d}$ & $2.1 \mathrm{~b}$ & $56.4 \mathrm{ab}$ & $467.2 \mathrm{e}$ \\
\hline RDA up to 1 year & & $13-14$ & $10-25$ & $<15$ & & & 650 \\
\hline
\end{tabular}

Note. Means of 3 independent determinations on dry weight basis.

Mean values in the same column with different superscripts differ significantly $(p<0.05)$.

Recommended dietary allowances from WHO (2004).

Table 4. Antinutritional composition of formulated complementary diets and nutrend (commercial weaning food)

\begin{tabular}{lllll}
\hline \multirow{2}{*}{ Sample } & \multicolumn{4}{c}{ Antinutritional Components $(\mathrm{mg} / 100 \mathrm{~g})$} \\
\cline { 2 - 5 } & Oxalate & Tannic acid & Phytic acid & Trypsin inhibitor \\
\hline RBGMF & $0.54 \pm 0.04 \mathrm{a}$ & $0.08 \pm 0.01 \mathrm{~b}$ & $14.12 \pm 0.25 \mathrm{c}$ & $3.30 \pm 0.20 \mathrm{~d}$ \\
BBGMF & $0.81 \pm 0.02 \mathrm{~b}$ & $0.16 \pm 0.02 \mathrm{a}$ & $19.70 \pm 0.80 \mathrm{c}$ & $5.00 \pm 0.20 \mathrm{~d}$ \\
SBGMF & $1.16 \pm 0.06 \mathrm{a}$ & $0.24 \pm 0.03 \mathrm{~b}$ & $27.25 \pm 0.46 \mathrm{c}$ & $7.40 \pm 0.50 \mathrm{~d}$ \\
Nutrend & $0.07 \mathrm{a}$ & $0.03 \mathrm{~b}$ & $0.05 \mathrm{c}$ & $0.03 \mathrm{~b}$ \\
\hline
\end{tabular}

Note. Means of 3 independent determinations.

Mean values in the same row with different superscripts differ significantly $(\mathrm{p}<0.05)$.

BBMGF: Boiled Bambara groundnut-maize germinated maize flour; SBMGF: Soaked Bambara groundnut-maize germinated flour; RBMGF: Roasted Bambara groundnut-maize germinated flour; Nutrend: commercial weaning food; RBG: Raw Bambara groundnut; RMF: Raw maize flour.

Table 5. Sensory qualities of the formulated complementary foods and nutrend samples

\begin{tabular}{llllll}
\hline \multirow{2}{*}{ Sample } & \multicolumn{5}{c}{ Attributes } \\
\cline { 2 - 6 } & Colour & Aroma & Taste & Mouth feel & Overall Acceptability \\
\hline RBMF & $5.00 \pm 0.82^{\mathrm{a}}$ & $6.00 \pm 0.69^{\mathrm{b}}$ & $6.00 \pm 0.62^{\mathrm{b}}$ & $5.57 \pm 0.81^{\mathrm{c}}$ & $6.29 \pm 0.47^{\mathrm{d}}$ \\
SBMDF & $6.29 \pm 0.36^{\mathrm{a}}$ & $5.71 \pm 0.42^{\mathrm{b}}$ & $5.71 \pm 0.18^{\mathrm{b}}$ & $5.43 \pm 0.75^{\mathrm{c}}$ & $5.71 \pm 0.29^{\mathrm{b}}$ \\
CBMDF & $6.14 \pm 0.59^{\mathrm{a}}$ & $5.43 \pm 0.78^{\mathrm{b}}$ & $4.86 \pm 0.40^{\mathrm{c}}$ & $6.00 \pm 0.54^{\mathrm{d}}$ & $5.57 \pm 0.48^{\mathrm{e}}$ \\
RBMGF & $7.43 \pm 0.29^{\mathrm{a}}$ & $7.14 \pm 0.34^{\mathrm{b}}$ & $7.14 \pm 0.34^{\mathrm{b}}$ & $7.86 \pm 0.63^{\mathrm{c}}$ & $7.71 \pm 0.52^{\mathrm{d}}$ \\
Nutrend & $9.00 \pm 0.00^{\mathrm{a}}$ & $9.00 \pm 0.00^{\mathrm{a}}$ & $8.86 \pm 0.14^{\mathrm{b}}$ & $8.43 \pm 0.20^{\mathrm{c}}$ & $8.86 \pm 0.14^{\mathrm{b}}$ \\
\hline
\end{tabular}

Note. Means of 3 independent determinations.

Mean values in the same row with different superscripts differ significantly $(\mathrm{p}<0.05)$. 


\section{Discussion}

Complementary foods are foods that are readily consumed and digested by young child and that provide addition nutrition to meet all the growing child's needs. Although exclusive breastfeeding provides the best start, after six months as long as breastfeeding continues (WHO/UNICEF, 1998).

In this study a wide variety of microorganisms were found associated with maize fermented meal blended with Bambara groundnut (Table 1). Previous studies suggest that micro-organisms are associated with cereal grains and their products and that the bacterial inoculum for natural fermentation process is derived from the grains (Odunfa \& Adeyele, 1985). The composition of the micro-population as well viable counts obtained showed a succession of Gram negative enteric bacteria and a mixed fungal population with lactic acid bacteria and yeasts, respectively (Figures 2-5). The yeast counts in the Bambara groundnut-maize fortified dough increased from $4.44 \pm 0.04$ to $5.80 \pm 0.24 \mathrm{log} \mathrm{cfu} / \mathrm{ml}$ after $48 \mathrm{~h}$ with a slight decrease thereafter. The increase in the yeast numbers after $24 \mathrm{~h}$ of fermentation is attributed to the decrease in the $\mathrm{pH}$ that creates conditions ideal for yeast growth (Serna-Saldivar \& Rooney, 1995). This is similar with the finding that is reported for other fermented beverages (Abegaz et al., 2002). The Lactobacillus spp ranged from $5.40 \pm 0.09$ to $7.36 \pm 0.00 \mathrm{log} \mathrm{cfu} / \mathrm{ml}$ during fermentation. The greatest increase in lactic acid bacteria was noted between $24 \mathrm{~h}$ and $48 \mathrm{~h}$. The acidic nature of the product could be due to the production of lactic acid produced by microorganism associated with maize dough fermentation. These microorganisms in a fermenting maize blended meal such as the one under study could originate from the flours, utensils and possibly from the tap water used for mixing. When water is added to flour, the micro-population in the flour begins to grow and metabolize. This process is the basis of the preparation of cereal gruels which are common weaning foods in developing countries (Akinrele, 1970).

In this study, lactic acid bacteria and yeast were found to be present at the end of the fermentation, with the dominating species being Lactobacillus spp. especially Lactobacillus plantarum as the most predominant organism and Lactobacilus delbrueckii the least in population. This was contrary to the report of Lonner et al. (1986) who found that all bacterial isolates from the final sour dough were homo-fermentative Lactobacilli and Pediococcus spp. Such variations in the composition of micro-flora can be accounted for by differences in incubation time, temperature, type of cereals used and mixture recipe among other factors. The results of molecular study of the isolates further confirmed the presence these microorganisms in the formulated diets. (Figures 2-5). The mold (Penicillium species) isolated in the study are commonly present as contaminants in cereals and do not appear to play any significant important role in the fermentation. Jespersen et al. (1994) similarly reported the presence of molds such as Penicillium and Aspergillus in maize fermentation during kenkey production with drastic reduction in their numbers from $10^{5}$ to less $10^{2} \mathrm{cfu} / \mathrm{g}$ within $24 \mathrm{~h}$ of dough fermentation. The subsequent disappearance of molds after $24 \mathrm{~h}$ observed in the present study as well as previous studies was probably due to the low oxygen tension in the fermenting matrix. According to Mensah et al. (1990), fermentation of cereals and legumes also has been reported to cause appreciable reductions of bacterial contamination of weaning foods. Previous workers have found several yeasts species in spontaneous lactic fermenting cereals including species of Saccharomyces and Candida (Jespersen, 1994). In the study, the duration of three days within which the $\mathrm{pH}$ of the formulated weaning foods decreased from 4.6 to 3.6, while the titratable acidity (TA) increased from 5.0 to $10.6 \mathrm{mg} \mathrm{NaOH} / \mathrm{g}$ sample (Table 2). The reduction in $\mathrm{pH}$ and increase in TA is in comparison with the findings of Plahar et al. (1997) who observed a similar situation in studies on dehydrated fermented maize meal fortified with defatted soy flour after fermentation. Granito et al. (2003) also found a dramatic decrease in the $\mathrm{pH}$ and increase in TA of beans (Phaseolus vulgaris) fermented from 24 to $72 \mathrm{~h}$ with L. acidophilus, Bifidobacterium and Streptococcus thermophilus. The rise in TA in the study is important to avoid proliferation of undesirable organisms resulting in poor fermentation. Generally, addition of whole Bambara groundnut (raw or heat-treated) or Bambara groundnut flour to the dough accelerated acid production. This was probably due to availability of more nutrients for microbial proliferation and enhanced metabolic activity. The desirable level of acid production was achieved within just $24 \mathrm{~h}$ of fermentation in samples in which Bambara groundnut flour had been incorporated before fermentation. The $\mathrm{pH}$ of Bambara groundnut-maize fortified dough was originally 4.6 and decreased to 3.6 during production of sourdough. There was complete disappearance of the coliforms after $24 \mathrm{~h}$ of fermentation as $\mathrm{pH}$ dropped to 3.9. Coliforms are acid intolerant (Steinkraus, 1996). The final $\mathrm{pH}$ of the dough was 3.6 after $72 \mathrm{~h}$.

Bambara groundnut maize dough samples are good sources of protein, fat and minerals. The superior quality of Bambara groundnut over maize in terms of fat and mineral is reflected in the higher values of these components determined in the Bambara groundnut-fortified samples. Fat and ash content increased with $30 \%$ levels of Bambara groundnut addition (Table 3). The protein content increased in maize as fermentation days progressed (Table 3). This improvement in protein content could be due to the proteolytic activities of enzymes produced by 
microorganisms during fermentation, which increase bioavailability of amino acids. Nanson and Field (1984) reported on the improvements in the concentrations of available lysine, methionine and tryptophan during fermentation of corn meal. The proximate composition of processed Bambara groundnut- maize composite blends, maize flour, and Bambara flour samples shows that the moisture content of boiled Bambara groundnut germinated maize flour blend was the highest $(11.24 \%)$, while that of roasted Bambara groundnut germinated maize flour blend was the lowest (3.3\%) (Table 3). However, investigations have shown that low moisture content of food samples is a desirable phenomenon, since the microbial activity is reduced (Temple et al., 1996). Low moisture content in food samples increased the storage periods of the food products (Alozie et al., 2009), while high moisture content in foods encourage microbial growth, hence, food spoilage (Temple et al., 1996). The protein content varied between 9.4\% raw maize flour (RMF) and $18.2 \%$ of raw Bambara groundnut. However, the protein content of the composite blends both germinated and fermented maize flour samples were significantly similar and higher than that of raw maize flour $(\mathrm{RMF})$ sample $(\mathrm{p}<0.05)$, but lower than raw Bambara groundnut. This observation agreed with other findings that processing techniques such as germination and fermentation improved the nutritional quality of the food products, particularly in terms of protein content (Enujiugha et al., 2003; Fasasi, 2009; Oluwole et al., 2012). In this present study, the protein content of soaked Bambara groundnut germinated maize flour blend was $15.18 \%$, significantly higher than maize flour $9.4 \%$ and other formulated foods, but also significantly lower than nutrend which has $23.21 \%$. This finding could be attributed to the fact that during fermentation the micro-organisms in food, utilized the carbohydrate and fat content in the food sample to synthesis amino acid needed for their growth and development (Wang et al., 1997).

There were significant differences in the fat content ranges from 9.15-10.85\%. Fat content was higher in roasted Bambara groundnut maize germinated flour blend $(21.3 \%)$ than that of nutrend (commercial weaning food) $(15.96 \%)$ but lower in other formulated processed foods. Crude fat increases as the inclusion of the fortified samples. The ash content of the formulation ranged from $2.8-4.18 \%$ more than the nutrend (commercial weaning food) which has $2.1 \%$. The ash content indicates the mineral compositions. The higher ash content indicates high levels of minerals in the formulated diets which implies that infants, feeding on weaning food formulation especially on soaked Bambara groundnut germinated maize flour (SBGMF) will not be mineral deficient (Fagbemi \& Oshodi, 1991). The highest crude fiber content (7.7\%) was in raw maize flour, and the lowest was in roasted Bambara groundnut maize germinated flour blend $(0.1 \%)$. A significant $(\mathrm{p}<0.05)$ difference was observed between the crude fiber content of formulated processed food samples, raw, and nutrend (commercial weaning diet). Giami (1993) also reported that germination resulted in significantly higher crude fiber content.

Carbohydrate and energy values of the raw Bambara groundnut and maize flour samples ranged between $63.60 \%$ to $66.20 \%$ for carbohydrate and $363.2 \mathrm{kcal}$ to $351 \mathrm{kcal}$ for energy. The carbohydrate content of the composite blends of germinated samples were lower than those of raw and fermented maize and Bambara groundnut flour samples, while the energy were also lower except for roasted Bambara groundnut maize germinated flour (RBGMF). The energy value of RBMGF was insignificantly high when compared with other formulated diets and maize flour (traditional complementary diet, corn gruel) $(\mathrm{p}>0.05)$, and nutrend (commercial weaning diet) (Table 3). According to Svanberg (1987), a good quality complementary diet must have high nutrient density, low bulk density, viscosity and appropriate texture. Also, complementary foods should be rich in energy, protein and micronutrients, and have a consistency that allows easy consumption. The high carbohydrate yield of these complementary formulated food blends makes them ideal for babies since they require energy for their rapid growth. The study therefore, conforms to energy need of infants from complementary foods as reported by Dewey and Brown (2003). This is because the energy needs from complementary foods for infants with "average" breast milk intake in developing countries (Dewey \& Brown 2003) are approximately 200 kcal per day at 6-8 months of age, $300 \mathrm{kcal}$ per day at 9-11 months of age, and $550 \mathrm{kcal}$ per day at 12-23 months of age.

The antinutritional factors of the formulated diets SBMGF was significantly higher of oxalate, phytic acid, and trypsin inhibitor $(\mathrm{p}<0.05)$, while RBMGF diet contained the least concentration of oxalate, tannic acid, phytic acid, and trypsin inhibitor of the formulated food samples (Table 4). The processing methods, adopted such as the combination of soaking, boiling, germination, fermentation and roasting, reduce the level of antinutritional factors in the formulated foods to tolerable levels thereby bioavailability of nutrients in the food products is enhanced. Several studies have reported that legumes, such as soybean, and Bambara groundnut, contain antinutritional or toxic components (Hwei-Ming et al., 1997), such as protease inhibitors, lectins, goitrogens, antivitamins, saponins, tannins, phytoestrogens, flatulence factors (Udensi et al., 2007), lysinoalanine, allergens, phytate (Urbano et al., 2000), soytoxin (Vasconcelos et al., 1999). Legumes consumption has been related to various deleterious effects, such as growth retardation (Martinez et al., 1995a), lowered digestibility and absorption of dietary nutrients (Drulyte \& Orlien, 2019) and physiological, metabolic and immunological 
disturbances (Rubio, 2000). However, it is evident that the antinutrient concentration in legumes can be eliminated or reduced to tolerable level through processing methods like roasting, fermentation and soaking (Agbede \& Aletor, 2003). Cooking resulted in decrease in tannin contents. The reductions are in agreement with reports by previous workers (Dlamini et al., 2007). The reductions in tannin after cooking may be due to thermally induced degradation (Awika et al., 2003) or interaction with other grain components such as proteins forming insoluble complexes (Emmambux \& Taylor, 2003), thus lowering tannin extractability and therefore reducing the amount assayed. Tannin contents were reduced drastically after boiling and dehulling (Rehman \& Salariya, 2005). Cooking generally inactivates heat-sensitive factors such as trypsin inhibitors as a result of denaturation of these heat-liable proteins (Vidal-Valverde et al., 1994). The observed reduction in phytic acid content of legume seeds during heat treatments may be partly due to the heat-labile nature of phytic acid and the formation of insoluble complexes between phytate and other components (Udensi et al., 2007). Germination has been reported (Traore et al., 2004) to reduce the concentration of antinutritional factors like phytates in malted grains hence improves its nutritional quality (Marero et al., 1989b). Fermentation of cereals and legumes also has been reported to cause appreciable reductions in the phytate content owing to endogenous phytase of both raw ingredients, inherent microorganisms and that of added yeast which hydrolyses phytic acid into inositol and orthophosphate (Sandberg \& Andlid, 2002).

All the sensory attributes of the formulated diets samples were significantly low compared to nutrend a commercial weaning food $(\mathrm{p}<0.05)$ (Table 5). The poor rating of the formulated diets samples in term of aroma, taste, texture and colour compared with the nutrend could also be attributed to the familiarity of the panel of judges to commercial weaning (nutrend) foods.

In conclusion, assessment of physicochemical and microbiological characteristics of the formulated foods blend prepared with Bambara groundnut and maize is nutritious and conformed to specifications as recommended by Food and Agriculture Organization (FAO) to combat malnutrition especially in low economic groups. It has special importance for use as weaning foods, catch-up growth and may improve birth weights. With proper selection and combination, it is possible to use local household foodstuff to formulate multimixes that can be used as home-based complementary foods. The blends formulated in this study are strongly recommended for use particularly by rural and poor urban mothers to feed their infants and children during the complementary feeding period. This will ensure availability and affordability as well as help in alleviating some economic and time-related constraints faced in child feeding practices. This research also showed that the processing methods used variously improved the nutrient content of the blends.

\section{Acknowledgements}

I wish to thank the Nigeria Tertiary Education Trust Fund (TETFUND) for financial support to complete this work. The authors are also grateful to the Management, Federal Polytechnic Nekede, Nigeria, for their interest in the study.

\section{References}

Abegaz, K., Fekadu, B., Langsrud, T., \& Narvhus, J. A. (2002). Indigenous process methods and raw materials of Borde, an Ethiopia traditional fermented beverage. J. Food Technol., 7(2), 59-64. https://doi.org/ 10.4314/jfta.v7i2.19246

Adelekan, A. O., \& Oyewole, O. B. (2010). Production of 'ogi' from germinated sorghum supplemented with soybeans. Afr. J. Biotechnol., 9(42), 7114-7121.

Agbaje, R. B., Oloye, D. A., Olatunji, C. A., \& Olawale-Olakunle, O. E. (2017). Antinutrient and mineral properties of complementary food produced from malted red sorghum and defatted soybean flour blend. Archive of Food and Nutritional Science, 1, 33-38. https://doi.org/10.29328/journal.afns.1001006

Agbede, J. O., \& Aletor, V. A. (2003). Comparative evaluation of weaning foods from Gliricidia and Leucaena leaf protein concentrates and some commercial brands in Nigeria. Journal Science Food Agriculture, 84, 21-30. https://doi.org/10.1002/jsfa.1563

Ahmed, M., Burhan, U., Akter, S., \& Eun, J. B. (2008). Effect of processing treatment on quality of cereal based soyabean fortified instant weaning food, Pakistan Journal of Nutrition, 7(3), 493-496. https://scialert.net/ abstract/?doi=pjn.2008.493.496

Akingbala, J. O., Rooney, K. W., \& Faubion, J. M. (1981). A laboratory procedure for the preparation of ogi: A Nigerian fermented food. Journal of Food Science, 45(5), 1523-1526 https://doi.org/10.1111/j.1365-2621. 1981.tb04212.x 
Akinrele, I. A. (1970). Fermentation studies on maize during preparation of traditional African starch cake food. Journal of Science Food and Agriculture, 21, 619-625. https://doi.org/10.1002/jsfa.2740211205

Akpapunam, M. A., \& Sefa-Dedeh, S. (1995). Traditional lactic acid fermentation, malt addition and quality development in maize-cowpea weaning blends. Food and Nutr. Bull., 16, 75-80. https://doi.org/10.1177/ 156482659501600113

Alozie, Y. E., Iyam, M. A., Lawal, O., Udofia, U., \& Ani, I. F. (2009). Utilization of Bambara groundnut flour blends in bread production, Journal of Food Technology, 7(4), 111-114. Retrieved from http://medwelljournals.com/abstract/?doi=jftech.2009.111.114

AOAC. (2000). Official Methods of Analysis (17th ed.). Association of Official and Analytical Chemists, Washington D.C.

Awika, J. M., Dykes, L., Gu, L., Rooney, L. W., \& Prior, R. L. (2003). Processing of sorghum (Sorghum bicolor) and sorghum product alters procanidin oligomer and polymer distribution and content. Journal of Agriculture Food and Chemistry, 51, 5516-5521. https://doi.org/10.1021/jf0343128

Ayernor, G. S., \& Ocloo, F. C. K. (2007). Physico-chemical changes and diastatic activity associated with germinating paddy rice (PSB.Rc 34). African Journal of Food Science, 1, 37-41.

Ayinde, F. A., \& Olusegun, A. I. (2003). Sensory evaluation, proximate composition and rheological value of fortified Gari using Bambara nut flour. Nigerian Food Journal, 21, 7-10.

Buta, M. B., \& Emire, S. A. (2015). Effects of fermentation on the nutritional quality of QPM and soybean blends for the production of weaning food. J Food Process Technol, 6, 507. https://doi.org/10.4172/ 2157-7110.1000507

Claus, D. C. (1992). A standardized gram staining procedure World Journal of Microbiology and Biotechnology, 8, 451-452. https://doi.org/10.1007/BF01198764

Dewey, K. G., \& Brown, K. H. (2003). Update on technical issues concerning complementary feeding of young children in developing countries and implications for intervention programs. Food Nutrition Bulletin, 24(1), 5-28. https://doi.org/10.1177/156482650302400102

Dlamini, N. R., Taylor, J. R. N., \& Rooney, L. W. (2007). The effect of sorghum type and processing on the antioxidant properties of African sorghum-based foods. Food Chemistry, 105, 1412-1419. https://doi.org/ 10.1016/j.foodchem.2007.05.017

Drulyte, D., \& Orlien, V. (2019). The Effect of Processing on Digestion of Legume Proteins. Foods, 8(6), 2-9. https://doi.org/10.3390/foods 8060224

Emmambux, N. M., \& Taylor, J. R. N. (2003). Sorghum kafirin interaction with various phenolic compounds. Journal of Sciences Food and Agriclture, 83, 402-407 https://doi.org/10.1002/jsfa.1379

Enujiugha, V. N., Badejo, A. A., Iyiola, S. O., \& Oluwamukomi, M. O. (2003). Effect of germination on the nutritional and functional properties of African oil bean (Pentaclethra macrophylla Benth) seed flour. Food Agriculture and Environment, 1, 72-75.

Fagbemi, T. N., \& Oshodi, A. A. (1991). Chemical composition and functional properties of full fat fluted pumpkin seed flour (Telfairia occidetalis). Nigerian Food Journal, 9, 26-32.

Fasasi, O. S. (2009). Proximate, antinutritional factors and functional properties of processed pearl millet (Pennisetum glaucum). Journal of Food Technology, 7(3), 92-97. Retrieved from http://medwelljournals. com/abstract/?doi=jftech.2009.92.97

FMOH (Federal Ministry of Health). (1999). Food-based dietary guidelines for Nigeria. Nutrition Division, Abuja.

Frey, D., Oldfield, R. J., \& Bridger, R. C. A. (1979). Colour atlas of pathogenic fungi, London. Wolfc Medical Publication Ltd.

Giami, S. Y. (1993). Effects of processing on the proximate composition and functional Properties of cowpea (Vigna unquiculata) flour. Food Chemistry, 47, 153-158. https://doi.org/10.1016/0308-8146(93)90237-A

Granito, M., Champ, M., Guerra, M., \& Frias, J. (2003). Effect of natural and controlled fermentation on flatus-producing compounds of beans (Phaseolus vulgaris), Journal of the Science of Food and Agriculture, 83(10), 1004-1009. https://doi.org/10.1002/jsfa.1388 
Hwei-Ming, B., Christian, V., Jean-Pierre, N., \& Luc, M. (1997). Effect of germination on chemical composition, biochemical constituents and antinutritional factors of soya beans (Glycine max) seeds. Journal of Science Food and Agriculture, 73, 1-9. https://doi.org/10.1002/(SICI)1097-0010(199701)73:1<1::AID-JSFA694> 3.0.CO;2-B

Ihekoronye, A. I., \& Ngoddy, P. O. (1991). Integrated Food Science and Technology for the Tropics (p. 386). Macmillan Publishers, Hong Kong.

Ijarotimi, O. S., Oyewo, M. T., \& Oladeji, B. S. (2009). Chemical, functional and sensory properties of roasted Bambara groundnut (Vigna subterranean L. Verdc) and cooking banana (Musa spp., ABB genome) weaning diet, African Journal of Food Science, 3(5), 139-146.

Jespersen, L., Halm, M., Kpodo, K., \& Jacobson, M. (1994). Significance of yeasts and moulds occurring in maize dough fermentation for kenkey production. Int. J. Food Microbiology, 24, 239-248. https://doi.org/ 10.1016/0168-1605(94)90122-8

Keregero, M. M., \& Kurwijila, R. L. N. (1987). Fermentation of cereal and legume based weaning foods. In D. Alnwick, S. Moses, \& O. G. Schmidt (Eds.), Improving young child feeding in Eastern and Southern Africa: Household level food technology. Proceedings of a workshop held in Nairobi, Kenya.

Kiiyukia, C. (2003). Laboratory Manual of Food Microbiology for Ethiopian Health and Nutrition Research Institute (Unido Project Ya/ETH/03/436/:11-54).

Kreger-van Rij, N. J. W. (1984). The Yeast: A Taxonomic Study (3rd ed.). Elsevier Science Publishers, Amsterdam.

Lonner, C., Welander, T., Molin, N., \& Dostalek, M, (1986). The Microflora in a sour dough started spontaneously on typical Swedish rye meal. Food Microbiology, 3, 3-12. https://doi.org/10.1016/ S0740-0020(86)80019-3

Mahgoub, S. E. O. (1999). Production and evaluation of weaning foods based on sorghum and legumes. Plant Foods Hum Nutr, 54, 29-42. https://doi.org/10.1023/a:1008151614247

Marero, L. M., Pagumo, E. M., Aguinaldo, A. R., \& Homma, S. (1989b). Nutritional characteristics of weaning foods prepared from germinated cereals and legumes. Journal of Food Science, 53(5), 1399-1402. https://doi.org/10.1111/j.1365-2621.1988.tb09286.x

Martinez, J. A., Marcos, R., Macarulla, M. T., \& Larralde, J. (1995a). Growth, hormonal status and protein turnover in rats fed on a diet containing peas (Pisum sativum L.) as the source of protein. Plant Foods for Human Nutrition, 47, 211-220. https://doi.org/10.1007/BF01088329

Mensah, P., Drasar, B. S., Harrison, T. J., \& Tomkins, A. M. (1990). Fermentation of cereals for reduction of bacterial contamination of weaning foods in Ghana. Lancet, 336(8708), 140-143. https://doi.org/ 10.1016/0140-6736(90)91660-3

Nanson, N. J., \& Field, M. L. (1984). Influence of Temperature on the nutritive value of lactic acid fermented corn meal. Journal of Food Sciences, 49, 958-959. https://doi.org/10.1111/j.1365-2621.1984.tb13253.x

Nti, C. A., \& Plahar, W. A. (1995). Chemical and biological characteristics of a West African weaning food supplemented with cowpea (Vigna unguiculata) Plant Foods Hum Nutr, 48, 45-54. https://doi.org/10.1007/ bf01089199

Odunfa, S. A., \& Adeyele, S. (1985). Microbiological changes during the traditional production of ogi-baba: A West African fermented sorghum gruel. Journal of Cereal Science, 3, 173-180. https://doi.org/10.1016/ S0733-5210(85)80027-8

Okwunodulu, N. I., Eze, N. L., Ndife, J., \& Ukom, N. A. (2019). Quality Characteristics of Soy-akamu powder formulated from sorghum and sprouted Soybean flour blends for Complementary Feeding. World Journal of Food Science and Technology, 3(4), 48-57 https://doi.org/10.11648/j.wjfst.20190304.12

Oluwole, O. B., Kosoko, S. B., Owolabi, S. O., Adeyoju, A. O., Bankole, A. O., Ozumba, A. U., \& Elemo, G. N. (2012). Development and production of high protein and energy density beverages from blends of maize (Zea mays), Sorghum (Sorghum bicolor) and Soybeans (Glycine max) for school aged children: Effect of malting period on selected proximate parameters and sensory qualities of developed beverages. International Journal of Applied Science and Technology, 2(7), 285-292. 
Onilude, A. A., Sanni, A. I., \& Ighalo, M. I. (1999). Effect of process Improvement on the physico-chemical properties of infant weaning food from fermented composite blends of cereal and soybeans. Plant Foods Hum Nutr, 54, 239-250. https://doi.org/10.1023/A:1008105521196

Onyenwe, N. E., Adeleke, O. E., Smith, S. I., Fowora, M. A., \& Mbata, T. I. (2012). Detection of mutations in gyrA gene that codes for point mutation in Floroquinolone resistant Salmonella enterica serotypes isolated from a hospital in South east Nigeria. Asian Journal of Pharmaceutical Health Science, 2(4), 353-357. https://doi.org/10.9734/BMRJ/2012/1595

Plahar, W. A., \& Leung, H. K. (1983). Composition of Ghana fermented maize meal and the effect of soy fortification on sensory properties J. Sci food Agric, 34, 407-411. https://doi.org/10.1002/jsfa.2740340414

Plahar, W. A., Nti, C. A., \& Annan, N. T. (1997). Effect of soy-fortification method on the fermentation characteristics and nutritional quality of fermented maize meal. Plant Foods for Human Nutrtion, 51, 365-380. https://doi.org/10.1023/a:1007996203309

Rehman, Z., \& Salariya, A. (2005). The effects of hydrothermal processing on antinutrients, protein and starch digestibility of food legumes. International Journal Food Science and Nutriton, 30, 695-700. https://doi.org/10.1111/j.1365-2621.2005.00978.x

Rubio, L. A. (2000). Physiological effects of legumes storage proteins. Nutrition Abstracts and Reviews, 70, 197-204

Salve, R. V., Mehrajfatema, Z. M., Kadam, M. L., \& More, S. G. (2011). Formulation, nutritional evaluation and storage study of supplementary food (Panjiri). Journal Food Process and Technology, 2(6), 2-5. https://doi.org/10.4172/2157-7110.1000131

Sandberg, A. S., \& Andlid, T. (2002). Phytogenic and microbial phytases in human nutrition. International Journal of Food Science and Technology, 37, 823-833. https://doi.org/10.1046/j.1365-2621.2002.00641.x

Sefa-Dedeh, S., \& Mensah, E. O. (1991). Traditional food processing technology and high proteins food production. Food and Nutr. Bull., 13, 43-49.

Sefa-Dedeh, S., Frimpong, K., Afoakwa, E. O., \& Sakyi-Dawson, E. (2000). Cowpea fortification of traditional foods. Presented at the World Cowpea Research Conference III, Ibadan, Nigeria, 4-7 September.

Serna-Saldiver, S., \& Rooney, L. W. (1995). Structure and Chemistry of millet. In D. Dendy (Ed.), Sorghum and Millets Chemistry and Technology (p. 69). American Association of cereal chemists, Minnesota.

Sneath, P. H. A., Mair, N. S., Sharpe, M. E., \& Holt, J. G. (1986). Bergey's Manual of Systematic Bacteriology (Vol. 2). Williams and Wilkins Co Baltimore.

Steinkraus, K. H. (1996). Classification of fermented foods: Worldwide review of household fermentation techniques. Food Control, 8(5/6), 311-317. https://doi.org/10.1016/S0956-7135(97)00050-9

Svanberg, U. (1987). Dietary bulk in weaning foods and its effect on food and energy intake. In D. Alnwick, S. Moses, \& O. G. Schmidt (Eds.), Improving young child feeding in Eastern and Southern Africa (pp. 272-287). Nairobi, New York, Stockholm: IDRC, UNICEF, SIDA.

Temple, V. J., Badamosi, E. J., Ladeji, O., \& Solomon, M. (1996). Proximate chemical composition of three locally formulated complementary foods. West African Journal of Biological Sciences, 5, 134-143.

Traore, T., Mouquet, C., Icard-Verniere, C., Traore, A. S., \& Treche, S. (2004). Changes in nutrient composition phytate and cyanide contents and amylase activity during cereal malting in small production units in Ouagadougou (Burkina Faso) Food Chemistry, 99(1), 105-114. https://doi.org/10.1016/j.foodchem. 2004.01.032

Udensi, E. A., Ekwu, F. C., \& Isinguzo, J. N. (2007). Antinutrient factors of vegetable cowpea (Sesquipedalis) seeds during thermal processing. Pakistan Journal of Nutrition, 6, 194-197. https://doi.org/10.3923/ pjn.2007.194.197

Urbano, G., Lopez-Jurado, M., Aranda, P., Vidal-Valverde, C., Tenorio, E., \& Porres, J. (2000). The role of phytic acid in legumes: antinutrient or beneficial function. Journal of Physiological Biochemistry, 56, 283-294. https://doi.org/10.1007/bf03179796

Vasconcelos, I. M., Siebra, E. A., Maia, A. A., Moreira, R. A., Neto, A. F., Campelo, G. J. A., \& Oliveira, J. T. A. (1999). Composition, toxic and antinutritional factors of newly developed cultivars of Brazilian soybean 
(Glycine max). Journal of Science Food and Agriculture, 75, 419-426. https://doi.org/10.1002/(SICI) 1097-0010(199712)75:4<419::AID-JSFA886>3.0.CO;2-D

Vidal-Valverde, C., Frias, J., Estrella, I., Gorospe, M. J., Ruiz, R., \& Bacon, J. (1994). Effect of processing on some antinutritional factors of lentils. Journal of Agriculture and Food Chemistry, 42, 2291-2295. https://doi.org/10.1021/jf00046a039

Wang, N., Lewis, M. J., Brennan, J. G., \& Westby, A. (1997). Effect of processing methods on nutrients and antinutritional factors in cowpea. Food Chemistry, 58, 59-68. https://doi.org/10.1016/S0308-8146(96) 00212-9

WHO/UNICEF. (1998). Complementary feeding of young children in developing countries: A review of current scientific knowledge. Geneva: World Health Organization, WHO/NUT/98.1.

\section{Copyrights}

Copyright for this article is retained by the author(s), with first publication rights granted to the journal.

This is an open-access article distributed under the terms and conditions of the Creative Commons Attribution license (http://creativecommons.org/licenses/by/4.0/). 